\title{
Fragile Xq27.3 in female heterozygotes for the Martin-Bell syndrome
}

\author{
Tessa Webb, Patricia A Jacobs
}

\begin{abstract}
$\mathbf{X}$ inactivation studies have been carried out on lymphocytes from eight unrelated females heterozygous for the Martin-Bell syndrome. Four of these carriers were of normal IQ and four were mentally handicapped. When BrdU was used to differentiate between the active and inactive $X$ chromosome an average of $55 \%$ of $\mathrm{fra}(\mathrm{X})$ were active in the retarded subjects, but only $27 \%$ were active in those of normal IQ. When ${ }^{3} \mathrm{H}$ thymidine was used to differentiate between the active and inactive $X$ chromosome, an average of $58 \%$ of mitoses from handicapped subjects and $33 \%$ of mitoses from normal subjects showed an active $f r a(X)$ in informative cells. These results are compared with previously published studies and it is concluded that the number of inactive fra $(X)$ chromosomes calculated as a proportion of all cells scored is the same in mentally normal and mentally retarded subjects. However, the number of active $\mathrm{fra}(\mathrm{X})$ chromosomes is consistently higher in the retarded than in the normal females.
\end{abstract}

Some of the many intriguing aspects of the cytogenetics and inheritance patterns shown in families with the fragile $\mathbf{X}$ syndrome are those associated with female carriers. One third of female heterozygotes are of impaired mental ability and nearly always have detectable levels of the fragile $\mathrm{X}$, while approximately one third of the carriers with a normal IQ do not show the marker with any culture method currently available. ${ }^{12}$ As a general rule those carrier females who are of impaired mental ability also show higher levels of fragile $\mathrm{X}$ than do normal carriers, although, as with

Department of Clinical Genetics, Birmingham Maternity Hospital, Edgbaston, Birmingham B15 2TG.

T Webb

Wessex Regional Genetics Laboratory, General Hospital, Salisbury, Wiltshire SP2 7SX.

P A Jacobs

Correspondence to Dr Jacobs.

Received for publication 23 January 1990

Revised version accepted for publication 27 April 1990 hemizygous males, the level of fragile $\mathrm{X}$ very rarely, if ever, exceeds $50 \%$. There is evidence that in the intellectually normal carrier females the level of detectable fragile $X$ is inversely proportional to the age of the subject. ${ }^{3}$ Neither the age effect nor the relationship between detectable fragile $X$ and IQ is shown by affected males. Despite the general relationships delineated above, both normal and handicapped female heterozygotes have been described with levels of fragile $X$ varying from 0 to $40 \%$.

One $\mathrm{X}$ chromosome in every cell with two $\mathrm{X}$ chromosomes is inactivated early in embryogenesis, so that only one $\mathrm{X}$ remains functional. This process of inactivation, or Lyonisation, is believed to be random so that approximately equal proportions of each $\mathrm{X}$ chromosome remain functional in any given female. ${ }^{4}$ However, in many situations where one $\mathrm{X}$ chromosome is structurally rearranged, Lyonisation appears non-random, and to be heavily 'skewed' in favour of the structurally abnormal chromosome in an aneuploid situation and in favour of the normal $X$ in balanced $\mathrm{X}$;autosome translocations. This apparent non-random inactivation is thought to be the result of selection of one or other type of cell after random inactivation. Such 'skewing' can also occur when one $\mathrm{X}$ chromosome carries a mutant gene. In this case the 'skewing' may be confined to certain tissues and usually results in virtually all cells having the nonmutant X chromosome active, for example, blood cells in females heterozygous for the Lesch-Nyhan syndrome. $^{5}$ However, in at least one condition, adrenoleucodystrophy, selection appears to favour the mutant cell line. ${ }^{6}$

Several studies have been carried out using incorporation of $\mathrm{BrdU}$ to distinguish between the early and late replicating $X$ chromosomes in $\mathrm{fra}(\mathrm{X})$ heterozygotes. A number of authors have found that mentally handicapped female carriers have an increased percentage of active fragile $\mathrm{X}$ chromosomes, whereas normal carriers tend to have a greater percentage of inactive fragile $X$ chromosomes. ${ }^{7-14}$ Other authors have not found this relationship to hold. In some studies the fragile site was found to be preferentially located on the active X chromosome in all carriers. ${ }^{15}$ 16 However, Nielsen et $a^{17}$ found an excess of early replicating or 'active' fragile $\mathrm{X}$ in all heterozygotes with high levels of the marker $X$ regardless of IQ, but 
in normal carriers with low levels of fragile $\mathrm{X}$ this tendency was reversed. Uchida $e t a l^{8}{ }^{18}$ found not only an inverse relationship between the proportion of active fragile $X$ in female heterozygotes and $I Q$, but that the difference between the two types of carrier, mentally impaired and normal, lay in the proportion of early or active fragile $\mathrm{X}$ chromosomes present in the carrier, the proportions being calculated on the basis of total cells scored and not on the basis of $\mathrm{fra}(\mathrm{X})$ positive cells alone. These authors found that the proportion of late replicating or inactive fragile $\mathrm{X}$ was the same in all female heterozygotes regardless of IQ but that variations in the proportion of early replicating or active fragile $\mathrm{X}$ chromosomes correlated with differences in IQ. Although these results were later confirmed by Tuckerman and $W e b b^{13}$ the numbers of subjects studied, particularly normal carriers, remains small. There are several reasons for this. Firstly, the normal carrier with a high level of fragile $\mathrm{X}$ is rare; secondly, the low levels of fragile $X$ shown by most normal carriers means that many hundreds of mitoses must be examined in order to detect enough fragile $X$ positive cells to make comparisons between early and late $\mathrm{X}$ chromosomes valid; thirdly, the addition of BrdU to the cell culture, while facilitating differentiation of early and late replicating $X$ chromosomes, causes a marked drop in the detectable level of fragile $X$ in all subjects. One study has indicated that the use of ${ }^{3} \mathrm{H}$ thymidine to differentiate between the active and inactive $\mathbf{X}$ chromosomes gives the same results as BrdU, without reducing the overall detection rate of fragile $X^{13}$

During the course of an investigation of fragile $X$ families, inactivation studies were carried out on the lymphocytes of a number of female heterozygotes using both the $\mathrm{BrdU}$ and ${ }^{3} \mathrm{H}$ thymidine methods where possible. In the patients in which both methods were used, BrdU but not ${ }^{3} \mathrm{H}$ thymidine was found to decrease the level of $\mathrm{fra}(\mathrm{X})$ expression. The number of active fra $(X)$ positive cells calculated on the basis of all informative cells scored was found to be positively correlated with mental impairment, while the number of inactive fra $(X)$ cells was similar in both normal and mentally retarded heterozygotes. Reanalysis of published case reports shows a similar correlation.

\section{Materials and methods}

Cultures of lymphocytes from eight female carriers of $\mathrm{fra}(\mathrm{X})(\mathrm{q} 27.3)$ were treated with either $\mathrm{BrdU}$ or 3HdTTP as described previously. ${ }^{13}$ Both methods were designed to allow the early and late replicating $\mathrm{X}$ chromosomes to be distinguished. Slides were first trypsin banded, the $\mathrm{X}$ chromosomes identified, and fragile $X$ positive cells drawn and the position of the two $X$ chromosomes marked. After destaining the slides with methanol, those containing BrdU were treated with Hoechst 33258 followed by treatment with UV light and SSC. ${ }^{19}$ Restaining of the cells with Leishman allowed identification of the active and inactive $\mathrm{X}$ chromosomes from the original drawings. In this way there could be no bias owing to difficulties in identifying the fragile site on the pale, late replicating $\mathrm{X}$ chromosome. Similarly, after destaining, slides containing ${ }^{3} \mathrm{H}$ thymidine were dipped into Ilford Nuclear Research emulsion K2 and kept in the dark at $4^{\circ} \mathrm{C}$ for 10 to 14 days before being developed and restained with Leishman. The early and late replicating $\mathrm{X}$ chromosomes were identified and their fragile $X$ status determined by comparison with the drawings. The late replicating fragile $X$ could not be distinguished once the autoradiograph had been developed, so previous drawings of all fragile $\mathbf{X}$ positive mitoses were essential.

Attempts were made to achieve at least 20 informative fragile $\mathrm{X}$ positive mitoses from each subject.

\section{Results}

Table 1 shows the results obtained from the inactivation studies carried out on cells from eight female fragile $\mathbf{X}$ carriers. In four of these carriers, two normal and two mentally retarded, both the BrdU and ${ }^{3} \mathrm{H}$ thymidine methods were used. The methods gave similar results

Table 1 The percentages of early replicating fragile $X$ present in normal and retarded carriers.

\begin{tabular}{|c|c|c|c|c|c|c|c|c|}
\hline $\begin{array}{l}\text { Subject and } \\
\text { method }\end{array}$ & IQ & $\begin{array}{l}\text { Total no } \\
\text { of cells } \\
\text { analysed }\end{array}$ & $\begin{array}{l}\text { No and (\%) } \\
\text { of cells with } \\
\text { fra }(\mathrm{Xq} 27)\end{array}$ & Early & $\begin{array}{c}\text { Non- } \\
\text { informative }\end{array}$ & Late & $\begin{array}{c}\text { Total } \\
\text { informative }\end{array}$ & $\%$ early \\
\hline $\begin{array}{ll}1 & \text { BrdU } \\
1 & \text { HdTTP } \\
2 & \text { BrdU } \\
2 & \text { 3dTTP } \\
3 & { }^{3} \text { HdTTP } \\
4 & { }^{3} \mathrm{HdTTP} \\
5 & \text { BrdU } \\
5 & { }^{3} \mathrm{HdTTP} \\
6 & \text { BrdU } \\
6 & { }^{3} \mathrm{HdTTP} \\
7 & \text { BrdU } \\
8 & \text { BrdU }\end{array}$ & $\begin{array}{c}\text { Normal } \\
\text { Normal } \\
\text { Normal } \\
\text { Normal } \\
\text { Normal } \\
\text { Normal } \\
\text { MR } \\
\text { MR } \\
\text { MR } \\
\text { MR } \\
\text { MR } \\
\text { MR }\end{array}$ & $\begin{array}{r}1588 \\
892 \\
468 \\
475 \\
306 \\
270 \\
828 \\
348 \\
914 \\
470 \\
540 \\
757\end{array}$ & $\begin{array}{c}67(4 \%) \\
99(11 \%) \\
20(4 \%) \\
85(18 \%) \\
91(30 \%) \\
40(15 \%) \\
65(8 \%) \\
95(13 \%) \\
37(4 \%) \\
128(27 \%) \\
50(9 \%) \\
34(4 \%)\end{array}$ & $\begin{array}{r}4 \\
19 \\
7 \\
21 \\
9 \\
7 \\
16 \\
45 \\
13 \\
29 \\
11 \\
16\end{array}$ & $\begin{array}{r}32 \\
11 \\
1 \\
27 \\
53 \\
26 \\
32 \\
20 \\
13 \\
75 \\
17 \\
9\end{array}$ & $\begin{array}{r}17 \\
69 \\
12 \\
37 \\
29 \\
7 \\
7 \\
30 \\
11 \\
24 \\
22 \\
9\end{array}$ & $\begin{array}{l}21 \\
88 \\
19 \\
58 \\
38 \\
14 \\
23 \\
75 \\
24 \\
53 \\
33 \\
25\end{array}$ & $\begin{array}{l}19 \\
22 \\
37 \\
36 \\
24 \\
50 \\
70 \\
60 \\
54 \\
55 \\
33 \\
64\end{array}$ \\
\hline
\end{tabular}


indicating that the use of BrdU does not introduce a bias. However, treatment with BrdU caused a marked reduction in the levels of fragile $\mathrm{X}$ detected in all cases, whereas treatment with the very low concentrations of ${ }^{3} \mathrm{HdTTP}$ required to differentiate the late replicating $\mathrm{X}$ chromosome caused no significant reduction in levels of fragile $X$.

It can be seen from table 1 that, after treatment with either BrdU or ${ }^{3} \mathrm{H}$ thymidine, three of the four retarded heterozygotes had percentages of early or active fragile $X$ greater than $50 \%$ of the informative mitoses. The exception, treated with BrdU only, had $33 \%$ of her informative fragile $\mathrm{X}$ early replicating. All four of the normal carriers had levels of active fragile $\mathrm{X}$ of $50 \%$ or below.

We then compared our results with other published studies but only considered those cases in which at least 10 informative fragile $X$ positive cells were reported. Table 2 compares the percentages of active and inactive fragile $\mathrm{X}$ chromosomes from 12 different studies with respect to heterozygote IQ. In every case the average value for the active fra $(\mathrm{X})$ chromosome was higher in the mentally retarded subjects than in the normal carriers. While there were some outliers, in most cases there was little or no overlap between the ranges shown by the two types of carrier. The 'outliers' were mainly normal carriers who had a high $(>10 \%)$ level of fragile $\mathrm{X}$ in their lymphocytes.

In tables 3 and 4 the percentages of $\mathrm{fra}(\mathrm{X})$ present in the lymphocytes of each subject have been multiplied by the percentage of either active or inactive fragile $X$. This gives an actual proportion of fragile $X$ present in the active or the inactive state. The proportion of active fragile $\mathrm{X}$ chromosomes calculated in this way may be a better estimate of a nonfunctional or mutated gene than a simple measurement of the percentage of detectable fragile $\mathrm{X}$ without considering whether it lies on an active or an inactive $\mathrm{X}$ chromosome.

For each of 11 studies, the proportions of both active and inactive fragile $X$ present in the lymphocytes of retarded and normal carriers in the presence

Table 2 Percentages of active fra $(X)$ with respect to $I Q$.

\begin{tabular}{|c|c|c|c|c|c|c|c|c|}
\hline \multirow[b]{3}{*}{ Reference } & \multicolumn{3}{|c|}{ MR subjects } & \multicolumn{3}{|c|}{ Normal subjects } & \multicolumn{2}{|c|}{ Outliers (exceptions) } \\
\hline & \multirow[b]{2}{*}{ No } & \multicolumn{2}{|c|}{ Active } & \multirow[b]{2}{*}{ No } & \multicolumn{2}{|c|}{ Active } & \multirow{2}{*}{$\begin{array}{l}\text { Mentally retarded } \\
\text { carriers with } \\
<50 \% \text { active fra }(X)\end{array}$} & \multirow{2}{*}{$\begin{array}{c}\text { Mentally normal } \\
\text { carriers with } \\
>50 \% \text { active fra }(X)\end{array}$} \\
\hline & & Range & Average & & Range & Average & & \\
\hline $\begin{array}{l}7 \\
17 \\
10 \\
8 \\
18 \\
9 \\
14 \\
15 \\
16 \\
12 \\
13 \\
\text { This study (BrdU) } \\
\text { This study } \\
\text { ( }{ }^{3} \text { H thymidine) }\end{array}$ & $\begin{array}{l}7 \\
9 \\
7 \\
2 \\
5 \\
1 \\
4 \\
7 \\
4 \\
7 \\
3 \\
4 \\
2\end{array}$ & $\begin{array}{l}13-81 \\
25-94 \\
73-96 \\
71-78 \\
71-95 \\
82 \\
85-96 \\
57-100 \\
58-100 \\
29-81 \\
50-86 \\
33-70 \\
55-60\end{array}$ & $\begin{array}{l}(58) \\
(63) \\
(82) \\
(74) \\
(83) \\
(82) \\
(91) \\
(76) \\
(73) \\
(59) \\
(70) \\
(55) \\
(58)\end{array}$ & $\begin{array}{l}2 \\
5 \\
7 \\
2 \\
5 \\
2 \\
3 \\
2 \\
\\
3 \\
4 \\
2 \\
4\end{array}$ & $\begin{array}{c}22-37 \\
16-86 \\
25-80 \\
31-51 \\
16-69 \\
22-51 \\
44-100 \\
70-76 \\
8-19 \\
30-42 \\
19-37 \\
22-50\end{array}$ & $\begin{array}{l}(30) \\
(57) \\
(60) \\
(41) \\
(40) \\
(37) \\
(65) \\
(73) \\
(15) \\
(37) \\
(27) \\
(33)\end{array}$ & $\begin{array}{l}2 / 7 \\
3 / 9 \\
0 / 7 \\
0 / 2 \\
0 / 5 \\
0 / 1 \\
0 / 4 \\
0 / 7 \\
0 / 4 \\
2 / 7 \\
0 / 3 \\
1 / 4 \\
0 / 2\end{array}$ & $\begin{array}{l}0 / 2 \\
3 / 5 \\
4 / 7 \\
0 / 2 \\
1 / 5 \\
0 / 2 \\
1 / 3 \\
2 / 2 \\
0 / 3 \\
0 / 4 \\
0 / 2 \\
0 / 4\end{array}$ \\
\hline
\end{tabular}

Table 3 Ranges of the proportions of active and inactive fragile $X$ chromosomes in mentally retarded and normal heterozygotes.

\begin{tabular}{|c|c|c|c|c|c|c|c|c|}
\hline \multirow[b]{3}{*}{ Reference } & \multicolumn{4}{|c|}{ Active } & \multicolumn{4}{|c|}{ Inactive } \\
\hline & \multicolumn{2}{|c|}{$\begin{array}{l}\text { Proportion in the } \\
\text { presence of BrdU }\end{array}$} & \multicolumn{2}{|c|}{$\begin{array}{l}\text { Proportion of total } \\
\text { by extrapolation }\end{array}$} & \multicolumn{2}{|c|}{$\begin{array}{l}\text { Proportion in the } \\
\text { presence of BrdU }\end{array}$} & \multicolumn{2}{|c|}{$\begin{array}{l}\text { Proportion of total } \\
\text { by extrapolation }\end{array}$} \\
\hline & MR & Normal & MR & Normal & MR & Normal & MR & Normal \\
\hline $\begin{array}{l}7 \\
17 \\
10 \\
8 \\
18 \\
14 \\
15 \\
16 \\
12 \\
13 \\
\text { This study } \\
\text { This study } \\
\text { ('HdTTP) }\end{array}$ & $\begin{array}{c}1 \cdot 8-23 \cdot 4 \\
2 \cdot 9-34 \cdot 0 \\
1 \cdot 0-15 \cdot 1 \\
2 \cdot 7-4 \cdot 7 \\
6 \cdot 3-24 \cdot 6 \\
10 \cdot 0-23 \cdot 0 \\
8 \cdot 0-27 \cdot 0 \\
12 \cdot 8-18 \cdot 0 \\
0 \cdot 9-7 \cdot 0 \\
2 \cdot 4-8 \cdot 3 \\
2 \cdot 2-5 \cdot 6 \\
7 \cdot 8-14 \cdot 9\end{array}$ & $\begin{array}{c}2 \cdot 7-7 \cdot 4 \\
3 \cdot 0-30 \cdot 0 \\
0 \cdot 2-13 \cdot 2 \\
0 \cdot 8-1 \cdot 4 \\
0 \cdot 1-11 \cdot 9 \\
0 \cdot 8-9 \cdot 0 \\
7 \cdot 7-14 \cdot 4 \\
10 \cdot 5 \\
0 \cdot 3-0.9 \\
0 \cdot 7-2 \cdot 5 \\
0 \cdot 8-1 \cdot 5 \\
2 \cdot 4-7 \cdot 5\end{array}$ & $\begin{array}{l}3 \cdot 6-32 \cdot 0 \\
\overline{-} \\
6 \cdot 0-6 \cdot 5 \\
\overline{13} \cdot 2-32 \cdot 2 \\
5 \cdot 7-26 \cdot 1 \\
\overline{5} \cdot 8-25 \cdot 9 \\
4 \cdot 7-28 \cdot 1 \\
9 \cdot 6-16 \cdot 8 \\
14 \cdot 4-16 \cdot 5\end{array}$ & $\begin{array}{l}3 \cdot 9-9 \cdot 6 \\
\overline{-} \\
0 \cdot 8-1 \cdot 9 \\
\overline{3} \cdot 1-15 \cdot 0 \\
7 \cdot 7-17 \cdot 5 \\
\overline{0} \cdot 5-5 \cdot 9 \\
2 \cdot 1-10 \cdot 1 \\
1 \cdot 9-9 \cdot 6 \\
2 \cdot 2-9 \cdot 4\end{array}$ & $\begin{array}{l}1 \cdot 3-12 \cdot 0 \\
2 \cdot 0-7 \cdot 9 \\
0 \cdot 2-2 \cdot 3 \\
1 \cdot 1-1 \cdot 4 \\
0 \cdot 5-4 \cdot 3 \\
1 \cdot 0-2 \cdot 0 \\
0-9 \cdot 7 \\
0-11 \cdot 9 \\
0 \cdot 4-2 \cdot 5 \\
0 \cdot 6-4 \cdot 7 \\
1 \cdot 4-6 \cdot 0 \\
5 \cdot 2-12 \cdot 1\end{array}$ & $\begin{array}{l}9 \cdot 5-12 \cdot 5 \\
2 \cdot 0-16 \cdot 0 \\
0 \cdot 3-3 \cdot 8 \\
0 \cdot 9-1 \cdot 4 \\
0 \cdot 7-5 \cdot 4 \\
0-1 \cdot 6 \\
3 \cdot 3-4 \cdot 6 \\
3 \cdot 5 \\
2 \cdot 4-4 \cdot 1 \\
1 \cdot 3-3 \cdot 5 \\
2 \cdot 5-3 \cdot 2 \\
7 \cdot 5-22 \cdot 8\end{array}$ & $\begin{array}{l}3 \cdot 0-24 \cdot 3 \\
\overline{1} \\
1 \cdot 7-2 \cdot 7 \\
\overline{1} \cdot 0-2 \cdot 8 \\
0-14 \cdot 0 \\
\overline{3 \cdot 8} \\
1 \cdot 0-16 \cdot 4 \\
5 \cdot 8-20 \cdot 4 \\
9 \cdot 6-16 \cdot 6\end{array}$ & $\begin{array}{l}13 \cdot 9-16 \cdot 4 \\
\overline{1} \\
\overline{1 \cdot 9} \\
0-5 \cdot 0 \\
3 \cdot 3-5 \cdot 5 \\
\overline{3 \cdot 3}-27 \cdot 1 \\
4 \cdot 9-13 \cdot 9 \\
8 \cdot 1-16 \cdot 4 \\
7 \cdot 0-17 \cdot 5\end{array}$ \\
\hline
\end{tabular}


Table 4 Averaged proportions of active and inactive fragile $X$ chromosomes in mentally retarded and normal heterozygotes.

\begin{tabular}{|c|c|c|c|c|c|c|c|c|}
\hline \multirow[b]{3}{*}{ Reference } & \multicolumn{4}{|c|}{ Active } & \multicolumn{4}{|c|}{ Inactive } \\
\hline & \multicolumn{2}{|c|}{$\begin{array}{l}\text { Proportion in the } \\
\text { presence of } \mathrm{BrdU}\end{array}$} & \multicolumn{2}{|c|}{$\begin{array}{l}\text { Proportion of total } \\
\text { by extrapolation }\end{array}$} & \multicolumn{2}{|c|}{$\begin{array}{l}\text { Proportion in the } \\
\text { presence of } \mathrm{BrdU}\end{array}$} & \multicolumn{2}{|c|}{$\begin{array}{l}\text { Proportion of total } \\
\text { by extrapolation }\end{array}$} \\
\hline & MR & Normal & MR & Normal & MR & Normal & MR & Normal \\
\hline $\begin{array}{l}7 \\
17 \\
10 \\
8 \\
18 \\
14 \\
15 \\
16 \\
12 \\
13 \\
\text { This study } \\
\text { This study } \\
\text { ( }{ }^{3} \text { HdTTP) }\end{array}$ & $\begin{array}{r}9 \cdot 7 \\
12 \cdot 3 \\
3 \cdot 8 \\
3 \cdot 7 \\
12 \cdot 0 \\
14 \cdot 5 \\
17 \cdot 6 \\
16 \cdot 0 \\
2 \cdot 8 \\
4 \cdot 7 \\
3 \cdot 3 \\
11 \cdot 4\end{array}$ & $\begin{array}{r}5 \cdot 1 \\
12 \cdot 8 \\
1 \cdot 7 \\
1 \cdot 1 \\
2 \cdot 8 \\
3 \cdot 7 \\
11 \cdot 1 \\
10.5 \\
0 \cdot 7 \\
1.5 \\
1.2 \\
5.9\end{array}$ & $\begin{array}{l}16 \cdot 2 \\
\overline{-} \\
6 \cdot 3 \\
\overline{21 \cdot 8} \\
16 \cdot 0 \\
\overline{14 \cdot 1} \\
13 \cdot 0 \\
13 \cdot 2 \\
15 \cdot 5\end{array}$ & $\begin{array}{c}6 \cdot 8 \\
\overline{-} \\
\frac{1}{7 \cdot 4} \\
7 \cdot 7 \\
12 \cdot 6 \\
\overline{2} \\
5 \cdot 4 \\
5 \cdot 8 \\
6 \cdot 0\end{array}$ & $\begin{array}{l}6 \cdot 6 \\
5 \cdot 0 \\
0 \cdot 7 \\
1 \cdot 3 \\
2 \cdot 1 \\
1 \cdot 5 \\
5 \cdot 1 \\
7 \cdot 0 \\
1 \cdot 6 \\
2 \cdot 3 \\
2 \cdot 9 \\
8 \cdot 7\end{array}$ & $\begin{array}{r}11 \cdot 0 \\
9 \cdot 1 \\
0 \cdot 9 \\
1 \cdot 2 \\
2 \cdot 1 \\
0 \cdot 9 \\
4 \cdot 0 \\
3 \cdot 5 \\
3 \cdot 4 \\
2 \cdot 5 \\
2 \cdot 9 \\
12 \cdot 6\end{array}$ & $\begin{array}{l}10 \cdot 7 \\
\overline{-} \\
\frac{2 \cdot 2}{\overline{2}} \\
4 \cdot 0 \\
\frac{\overline{9}}{9 \cdot 3} \\
7 \cdot 0 \\
10 \cdot 2 \\
11 \cdot 6\end{array}$ & $\begin{array}{l}15 \cdot 2 \\
\overline{-} \\
1 \cdot 9 \\
\overline{3 \cdot 0} \\
4 \cdot 4 \\
\overline{12 \cdot 0} \\
7 \cdot 9 \\
12 \cdot 3 \\
12 \cdot 2\end{array}$ \\
\hline
\end{tabular}

of BrdU are shown and, where possible, these values have been extrapolated to give the proportions of active and inactive fra $(X)$ present in cultures which did not contain BrdU. Table 3 gives ranges of values, showing that there is complete overlap between mentally retarded and normal carriers in the proportion of inactive $\mathrm{fra}(\mathrm{X})$ chromosomes. However, there is almost no overlap at all between the proportions of active $\mathrm{fra}(\mathrm{X})$ chromosomes in retarded and normal subjects, the ranges for the retarded heterozygotes being higher in every case. Levels of active fragile $\mathrm{X}$ are thus higher in the mentally retarded than in the normal carriers, but levels of inactive fragile $\mathrm{X}$ are the same in both groups. These differences become more obvious in table 4 where the values have been averaged for each study. The average proportion of inactive $\mathrm{fra}(\mathrm{X})$ is the same for both retarded and normal heterozygotes, but in each study the proportion of active fragile $\mathrm{X}$ is greater in mentally retarded than in normal heterozygotes.

\section{Discussion}

Studies of the replication status of the fragile $\mathrm{X}$ chromosome in female heterozygotes using both BrdU and ${ }^{3} \mathrm{H}$ thymidine confirmed the observation that BrdU but not ${ }^{3} \mathrm{H}$ thymidine markedly reduces the number of cells showing the fragile site at Xq27. ${ }^{13}$ The present study of eight unrelated heterozygotes for the fragile $\mathrm{X}$ syndrome shows a direct relationship between the percentage of fragile $X$ that is active or early replicating and mental status. Although the number of uninformative cells was in some cases disconcertingly high, there was no consistency in the percentages observed either between normal and retarded patients or between cultures treated with ${ }^{3}$ HdTTP or BrdU. The conclusions were therefore not biased by the methodology. In general, heterozygotes of normal intelligence have percentages of active fragile $\mathrm{X}$ below $50 \%$ and mentally handicapped heterozygotes a level of active fragile $\mathrm{X}$ above $50 \%$. This finding holds true whether the activation studies use $\mathrm{BrdU}$ or ${ }^{3} \mathrm{H}$ thymidine to differentiate between the $\mathrm{X}$ chromosomes. Because the addition of $\mathrm{BrdU}$ to the culture medium reduces levels of detectable fragile $\mathrm{X}$, there are very few studies on normal carriers with low fra $(\mathrm{X})$ levels. As these women are in the majority, it is to be hoped that studies using ${ }^{3} \mathrm{Ho}$ thymidine may indicate whether this type of carrier has less than $50 \%$ active fragile $\mathrm{X}$ chromosomes. It is reasonable to assume that the phenotypic effect may be related to the actual numbers of active fragile $\mathbf{X}$ chromosomes present. Therefore the detectable levels of fragile $\mathrm{X}$ in the culture must be taken into account as well as the ratio of early/late replicating $X$ chromosomes. When this is done (tables 3 and 4) there is an obvious difference between the proportion of active fragile $\mathrm{X}$ chromosomes in the normal and mentally retarded heterozygotes. In contrast, the proportions of inactive fragile $\mathrm{X}$ are similar in all cases regardless of IQ. This confirms the observation made by Uchida $e t$ al $^{18}$ on eight retarded and six normal heterozygotes.

It appears that in both normal and retarded heterozygotes the status of the inactive $\mathrm{X}$ chromosome renders it less inducible to $\mathrm{fra}(\mathrm{X})$ expression. The small proportion of mentally normal female heterozygotes who have high levels of $\mathrm{fra}(\mathrm{X})$ positive cells appear to be exceptional in that their $\mathrm{fra}(\mathrm{X})$ is easily expressed. Our study is, of course, biased towards these exceptional females. The majority of normal heterozygotes have no or a very low level of expression of $\mathrm{fra}(\mathrm{X})$ positive cells because their fragile $\mathrm{X}$ cells are inactive and so less inducible to expression.

It is perhaps surprising that there should be a relationship between fragile $X$ expression in female heterozygotes and the proportion of active fragile $\mathrm{X}$ chromosomes in peripheral blood cells, as the level of 
mental ability is likely to be correlated with the proportion of active fragile $\mathrm{X}$ chromosomes in neural tissue rather than in lymphocytes. Our observations suggest that the level of active fragile $\mathrm{X}$ chromosomes seen in peripheral lymphocytes may reflect the proportion in neural or other cells that are responsible for mental development.

1 Sherman SL, Morton NE, Jacobs PA, Turner G. The marker (x) syndrome: a cytogenetic and genetic analysis. Ann Hum Genet 1984;48:21-37.

2 Nussbaum RL, Ledbetter DM. Fragile X syndrome: a unique mutation in man. Annu Rev Genet 1986;20:109-45.

3 Jacobs PA, Glover TW, Mayer M, et al. X-linked mental retardation: a study of 7 families. Am 7 Med Genet 1980;7: 471-89.

4 Lyon MF. X-chromosome inactivation and developmental patterns in mammals. Biol Rev 1972;47:1-35.

5 Albertini RJ, Demars R. Mosaicism of peripheral blood lymphocyte populations in females heterozygous for the Lesch-Nyhan mutation. Biochem Genet 1974;11:379-82.

6 Migeon BR, Moser HW, Moser AB, Sprenkle JA, Sillence D, Norum RA. Adrenoleukodystrophy: evidence for X-linkage inactivation and selection favoring the mutant allele in heterozygous cells. Proc Natl Acad Sci USA 1981;78:5066-70.

7 Knoll JH, Chudley AE, Gerrard JW. Fragile (X) X-linked mental retardation. II. Frequency and replication pattern of fragile $(\mathrm{X})$ (q28) in heterozygotes. Am $\mathcal{f}$ Hum Genet 1984;36:640-5.

8 Uchida IA, Joyce EM. Activity of the fragile $\mathrm{X}$ in heterozygous carriers. Am f Hum Genet 1982;34:286-93.
9 Howell RT, McDermott A. Replication status of the fragile X chromosomes, $\mathrm{fra}(\mathrm{X})(\mathrm{q} 27)$ in three heterozygous females. Hum Genet 1982;62:282-4.

10 Paul J, Froster-Iskenius U, Moje W, Schwinger E. Heterozygous female carriers of the marker-X chromosome: IQ estimation and replication status of $\mathrm{fra}(\mathrm{X})(\mathrm{q})$. Hum Genet 1984;66:344-6.

11 Tuckerman E, Webb T, Bundey SE. Frequency and replication status of the fragile (X) (q27-28) in a pair of monozygotic twins of markedly differing intelligence. $\mathcal{F}$ Med Genet 1985;22:85-91.

12 Tuckerman E, Webb T, Thake A. Replication status of fragile $\mathrm{X}(\mathrm{q} 27.3)$ in 13 female heterozygotes. 7 Med Genet 1986;23: 407-10.

13 Tuckerman $E$, Webb $T$. The inactivation of the fragile $X$ chromosome in female carriers of the Martin Bell syndrome as studied by two different methods. Clin Genet 1989;35:25-30.

14 Wilhelm D, Froster-Iskenius U, Paul J, Schwinger E. Fra(X) frequency on the active $\mathrm{X}$-chromosome and phenotype in heterozygous carriers of the fra $(\mathbf{X})$ form of mental retardation. Am $\mathcal{F}$ Med Genet 1988;30:407-15.

15 Fryns JP, Kleczkowska A, Kubien E, Petit P, Van den Berghe H. Inactivation pattern of the fragile $\mathrm{X}$ in heterozygous carriers. Hum Genet 1984;65:400-1.

16 Fryns JP, Van den Berghe H. Inactivation pattern of the fragile-X in heterozygous carriers. Am $\mathcal{F}$ Med Genet 1988;30:401-6.

17 Nielsen KB, Tommerup N, Poulsen H, Jacobsen P, Beck B, Mikkelsen $\mathbf{M}$. Carrier detection and $\mathrm{X}$-inactivation studies in the fragile X syndrome. Hum Genet 1983;64:240-5.

18 Uchida IA, Freeman VCP, Jamro H, Partington MW, Soltan HC. Additional evidence for fragile $\mathrm{X}$ activity in heterozygous carriers. Am f Hum Genet 1983;35:861-8.

19 Schempp W, Meer B. Cytologic evidence for three human Xchromosomal segments escaping inactivation. Hum Genet 1983; 63:171-4. 